\title{
ETNOMETODOLOGI PRICE SETTING PADA WARUNG MAKAN MBA CITRA
}

\author{
Juniaty Ismail \\ Fakultas Ekonomi dan Bisnis Islam, IAIN Sultan Amai Gorontalo \\ Email : juniatyismail@iaingorontalo.ac.id
}

\begin{abstract}
ABSTRAK
Tujuan studi ini adalah untuk menyelidiki bagaimana cara menentukan harga penjualan pada warung makan Mba Citra yang sebagai pemilik sekaligus pegelolanya, Mba Citra dan Suaminya Mas Djarwo yang menerapkan kearifan budayanya sebagai orang Jawa dalam kehidupan sehari-harinya terutama dalam kegiatan usaha warung makannya yang didirikan sejak tahun 90-an. Studi ini menggunakan pendekatan etnomethodology. Studi menunjukkan bahwa dalam penetapan harga atau price setting pada warung makan ini, tidak seperti warung makan lainnya yang menginginkan keutungan yang sebesar-besarnya, tetapi pengelolanya lebih mengutamakan niat untuk menolong memenuhi kebutuhan pokok pelanggannya yang didominasi oleh anak-anak kos.
\end{abstract}

Kata kunci: Kultur Jawa, Price Setting, Warung Makan, Etnometodology

ABSTRACT

The purpose of this study is to investigate how to determine the selling price of Mba Citra's food stalls, which as the owner and manager, Mba Citra and her husband, Mas Djarwo, who apply their cultural wisdom as Javanese in their daily lives, especially in the business of food stalls, which was established since the year of 90s. This study uses the ethnomethodology approach. Studies show that in setting prices or price settings in this food stall, unlike other food stalls that want maximum profitability, but managers prefer the intention to help meet the basic needs of customers who are dominated by boarding children.

Keywords: Javanese Culture, Price Setting, Food Stalls, Etnometodology

\section{PENDAHULUAN}

Usaha atau bisnis yang tidak pernah mati salah satunya adalah usaha kuliner, pelanggannya akan selalu ada, meliputi segmen yang tak terbatas, karena bisnis kuliner menyediakan kebutuhan pokok masyarakat. Terlebih untuk bisnis kuliner yang berada di komplek penyedia jasa rumah-rumah kos. Dapat menjadi nilai tambah tersendiri bagi pebisnis kuliner ataupun warung makan, yang tidak akan pernah sepi pelanggan dari pagi, siang, sore dan malam hari untuk memenuhi kebutuhan pokok bagi warga pendatang yang tinggal di kos-kosan.

Prospek yang bagus dan lokasi yang mendukung menunjukkan bahwa bisnis ini mempunyai potensi yang lumayan besar dalam menghasilkan laba. Warung makan Mba Citra ini merupakan salah satu dari beberapa warung makan yang tersedia di lingkungan Wessabe. Sebagai pemilik sekaligus pengelola warung makan ini, Mba Citra dan suaminya Mas Djarwo yang notabene adalah berasal dari etnis Jawa dimana orang Jawa memiliki etos kerja yang kuat dan disiplin tinggi.

Etos kerja ini diajarkan pertama kalinya oleh para orang tua kepada anaknya ketika mereka sudah berumur akil baligh. Nilai-nilai yang ditanamkan orang tua kepada anaknya tersebut adalah terkait dengan kewajiban dalam mencari penghidupan (pemenuhan kebutuhan 
hidup sehari-hari). Mereka akan terus mendorong anaknya dengan memberikan nilai-nilai yang arif dan memberikan sebuah perumpamaan-perumpamaan sebagai tuladha (contoh).

Dalam etos berbisnis orang Jawa sangat memegang prinsip-prinsip leluhurnya. Ketika memulai untuk melakukan aktivitas bisnis para orang tua mengingatkan Gusti ora sare "Tuhan tidak tidur". Ungkapan ini memiliki makna bahwa kita harus memulai aktivitas dengan memohon apa yang kita inginkan.

Prinsip penting orang Jawa dalam etos dagang adalah ungkapan jujur bakal mujur “jujur akan bahagia”. Jadi, orang Jawa berkeyakinan bahwa seseorang yang berani dan selalu berperilaku jujur akan mendapatkan kebahagiaan. Orang yang mampu berlaku jujur akan memiliki keuntungan karena apa pun alasannya, orang yang mampu bersikap jujur akan mendapatkan ketenangan hati dan dirinya tidak merasa bersalah.

Disamping itu, jurus jitu dalam kebanyakan bisnis adalah penentuan harga atau price setting. Penentuan harga adalah hal yang paling pokok dan penting dalam melakukan kegiatan usaha atau bisnis, baik berupa usaha jual beli barang, jasa ataupun yang lainnya. Tokoh bisnis India R.S.N. Villai dan Bagavathi dalam bukunya "Modern Marketing principles and Practices" menjelaskan tidak hanya satu definisi harga, tapi banyak definisi, mulai dari harga sebagai regulator ekonomi, sebagai penentu kesuksesan perusahaan, sumber utama pendapatan dimana seluruh perusahaan akan memaksimalkan pendapatan dari pembentukan harga, dan masih banyak lagi.

Harga menjadi hal yang sangat penting, penentuannya tidak boleh asal-asalan, karena menjadikan senjata yang potensial dalam proses menguasai pasar. Penelitian ini bertujuan untuk mendeskripsikan bagaimana penentuan harga yang diterapkan oleh kebudayaan Jawa dalam usaha warung makan Mba Citra.

\section{LANDASAN TEORI}

Bagi kalangan awam, penentuan sebuah harga produk merupakan hal yang sepele, kebanyakan dari mereka hanya menetapkan harga secara asal-asalan agar mendapatkan keuntungan, sebab menurut mereka ini merupakan cara tercepat dalam menentukan harga, namun bagaimana jika kita memiliki banyak pesaing yang memiliki jenis usaha yang sama, apakah penentuan harga yang asal-asalan akan tetap diterapkan dalam penentuan harga?.

Penentuan harga menggambarkan biaya produksi yang dikeluarkan oleh suatu usaha ditambah dengan target laba yang diinginkan. Jika biaya produksi atau target labanya besar, maka semakin besar pula harga jual yang terbentuk. Menentukan harga yang terlalu tinggi mampu membuat pelanggan akan beralih ke pesaing, sebaliknya bila menentukan harga 
terlalu rendah resikonya usaha tersebut hanya akan mengalami kerugian, oleh karenanya kegiatan yang sangat penting dalam suatu usaha adalah proses penentuan harga.

Kotler dan Amstrong (2001), menjelaskan harga adalah sejumlah uang yang ditukarkan untuk sebuah produk atau jasa. Lebih jauh lagi, harga adalah sejumlah nilai yang konsumen tukarkan untuk jumlah manfaat dengan memiliki atau menggunakan suatu barang atau jasa. Harga merupakan hal yang diperhatikan konsumen saat melakukan pembelian.

Djaslim Saladin (2006), menjabarkan tujuan penetapan harga yaitu; 1). Bertahan hidup (survival), pada kondisi tertentu (karena adanya kapasitas yang menganggur, persaingan yang semaikin gencar atau perubahan keinginan konsumen, atau mungkin juga kesulitan keuangan), maka perusahaan menetapkan harga jualnya dibawah biaya total produk tersebut atau bibawah harga pasar. Tujuannya adalah bertahan bidup (survival) dalam jangka pendek. Untuk berahan hidup jangka panjang, harus mencari jalan keluar lainnya. 2). Memaksimalkan laba jangka pendek (maximum current profit), perusahaan merasa yakin bahwa dengan volume penjualan yang tinggi akan mengakibatkan biaya per unit lebih rendah dan keuntungan yang lebih tinggi. Perusahaan menetapkan harga serendah-rendahnya dengan asumsi pasar sangat peka terhadap harga. 3). Memaksimalkan hasil penjualan (maximum current revenue), untuk memaksimalkan hasil penjualan, perusahaan perlu memahami fungsi permintaan. Banyak perusahaan berpendapat bahwa maksimalisasi hasil penjualan itu akan mengantarkan perusahaan memperoleh maksimalisasi laba dalam jangka panjang dan pertumbuhan bagian pasar. 4). Menyaring pasar secara maksimum (maximum market skiming), banyak perusahaan menetapkan harga untuk menyaring pasar (market skiming price). Hal ini dilakukan untuk menarik segmen-segmen baru. Mula-mula dimunculkan ke pasar produk baru dengan harga tinggi, beberapa lama kemudian dimunculkan produk baru dengan harga tinggi, beberapa lama kemudian dimunculkan pula produk yang sama dengan harga yang lebih rendah. 5). Menentukan permintaan (determinant demand). Penetapan harga jual membawa akibat pada jumlah permintaan.

Banyak faktor yang menentukan cara-cara dalam penentuan harga, yakni dimulai dari tujuan perusahaan, faktor budaya yang dimiliki investor ataupun pemilik, banyaknya pesaing, jenis usaha dan lain-lainnya. Penentuan harga inilah yang membuatnya berbeda dengan satu bisnis dengan bisnis lainnya, sehingga kita tidak mungkin mendapatkan hal yang sama bilamana kita meniru cara penentuan harga bisnis lain ataupun pesaing.

Menurut Kotler dan Armstrong (2001), pengungkapan keputusan-keputusan penetapan harga tergantung pada serangkaian kekuatan-kekuatan lingkungan dan persaingan yang sangat 
rumit. Perusahaan tidak hanya menetapkan satu harga tunggal, tetapi lebih berupa sebuah struktur penetapan harga (pricing structure) yang mencakup item-item yang berbeda disetiap lini produk. Perusahaan menyesuaikan harga produk supaya dapat mencerminkan perubahanperubahan biaya dan permintaan serta memperhitungkan berubah-ubah pembeli dan situasi. Ketika lingkungan persaingan berubah, perusahaan itu mempertimbangkan kapan memprakarsai perubahan harga dan kapan menanggapi perubahan harga di pasar.

Harga yang tepat mampu meramalkan laba yang akan didapat. Banyaknya selisih lebih dari pendapatan yang didapat dibanding dengan beban dalam usaha untuk memperoleh pendapatan dalam kurun periode tertentu disebut dengan laba (Soemarso, 2004:245).

Sehingga dapat diambil kesimpulan, Warung Makan sebagai salah satu usaha kuliner yang sangat membantu untuk memenuhi kebutuhan pokok para pelanggannya menjadi pilihan tersendiri bagi para pedagang untuk membuka usaha ini dengan perolehan penghasilan yang lumayan menguntungkan. Terlebih untuk sebuah warung makan sederhana yang didirikan dan dikelola oleh Mba Citra bersama Suami sejak Tahun 90-an dengan tujuan utama untuk memenuhi kebutuhan pokok para pelanggannya yang kebanyakan adalah mahasiswa dan anak kos-kosan.

Selain itu, untuk sistem penentuan harga yang diterapkan oleh Warung Makan Mba Citra adalah dengan penentuan harga yang unik dengan memasukkan konsep kebudayaan yang membuat warung makan Mba Citra ini mampu bertahan dari tahun 90-an hingga sekarang dan memiliki pelanggan tetap setiap harinya.

\section{Kebudayaan Jawa}

Suku Jawa adalah suku yang dikenal dengan kebiasaan merantau dan pekerja keras. Budaya Jawa adalah budaya yang berasal dari Jawa dan dianut oleh masyarakat Jawa khususnya di Jawa Tengah, DIY dan Jawa Timur. Budaya Jawa secara garis besar dapat dibagi menjadi 3 yaitu budaya Banyumasan, budaya Jawa Tengah-DIY dan budaya Jawa Timur.

Budaya Jawa mengutamakan keseimbangan, keselarasan dan keserasian dalam kehidupan sehari hari. Budaya Jawa menjunjung tinggi kesopanan dan kesederhanaan. Budaya Jawa selain terdapat di Jawa Tengah, DIY dan Jawa Timur terdapat juga di daerah perantauan. Orang Jawa sebagian besar secara nominal menganut agama Islam.

Perilaku orang jawa yang tercermin dalam falsafah hidup dan etos kerjanya dalam melakukan praktik di medan kehidupan sehari-hari dengan bekal capital yang dimilikinya. 
Nilai-nilai kearifan budaya Jawa dalam konteks praktik bisnis paling tidak meliputi obahmamah-sanak.

Perilaku obah (bekerja) bagi sebagian besar orang Jawa adalah merupakan sesuatu yang harus segera dipraktikan di mana pun tempatnya mereka berada dan dengan seluruh kemampuan (capital) yang dimilikinya. Konsekwensi positif dari perilaku obah adalah akan memunculkan mamah (makan).

Mamah sebenarnya merupakan bagian dari rizqi yang Tuhan berikan. Mamah bukan hanya sekedar makan dalam konteks menyambung hidup saja melainkan diharapkan menyisakan sesuatu yang dapat ditabung untuk kebutuhan jangka panjang. Meskipun orang Jawa meyakini bahwa hal tersebut berasal dari sangkan paran (berasal dari Tuhan yang diberikan dari arah manapun baik halal maupun haram), namun mereka tetap menjaga agar rizqi yang didapat memperoleh berkah dari Tuhan Yang Maha Esa.

Sebagaimana dengan ungkapan tuna satak bathi sanak dalam pergaulan para bakul (pedagang). Artinya, rugi uang asal untung saudara. Ungkapan yang sering ditemukan dalam pergaulan para bakul (pedagang) tersebut menunjukkan bahwa kebahagiaan orang berdagang tidak selalu diukur dengan keuntungan berupa uang. Bagi seorang pedagang yang dalam bahasa jawa disebut bakul, mendapatkan saudara atau rekanan dalam berusaha pun dihitungnya sebagai keuntungan (laba).

Oleh sebab itu, seorang pedagang rela menjual barang dagangannya dengan harga sedikit lebih rendah dari penawarannya demi menjalin hubungan dengan orang lain, yakni pembeli. Bagi orang Jawa harta bukanlah segala-galanya. Ukuran kekayaan seseorang pun tidak selalu ditentukan dengan banyaknya harta yang dimiliki. Manusia jawa merupakan sosok yang dapat menerima kondisi atau nasib yang terjadi dalam hidupnya dengan dilandasi rasa percaya pada kemurahan Tuhan sehingga segala sesuatu diterima dengan jiwa yang lapang (Marbangun, 1995: 65).

Sikap hidup yang mencerminkan kerukunan tersebut tidak terlepas dari sikap tepo slira (tenggang rasa). Jika persaudaraan menjadi pertimbangan yang khusus, maka seorang bakul tidak mungkin menipu pembeli dengan menjual harga tinggi untuk barang berkwalitas rendah. Lagi pula pedagang yang memiliki cara berpikir Jawa tidak akan nuthuk rega (menipu dengan harga tinggi). Penipuan berbentuk nuthuk rega akan mengecewakan para pembeli dan menjauhkan pedagang dengan pelanggannya. Orang Jawa meyakini bahwa perbuatan menipu orang lain merupakan tindakan negatif. Dengan berbekal kesadaran bahwa nandur bakal ngundhuh "menanam akan memetik" atau ngundhuh wohing pakarti "memetik buah 
perbuatan", sikap dan perilaku orang Jawa sesungguhnya dikendalikan oleh cahaya hati nurani untuk menjauhi perbuatan nistha.

\section{METODE PENELITIAN}

Penelitian ini menggunakan metode penelitian deskriptif-kualitatif. Penggunaan metode kualitatif dalam penelitian ini dimaksudkan untuk mendeskripsikan bagaimana Mba Citra dan Suaminya Mas Djarwo yang notabene adalah berasal dari etnis Jawa yang mempunyai usaha Warung Makan dan secara sederhana menerapkan sistem penentuan harganya.

Menurut Moleong (2004) dalam pendekatan kualitatif peneliti ikut berperan serta saat pengumpulan data dilakukan dan peneliti tidak selamanya berada di luar objek studi tersebut melainkan menjadi bagian dari objek tersebut. Data yang dikumpulkan berupa kata-kata, gambar dan bukan angka-angka. Hal ini disebabkan oleh adanya penerapan dari metodologi kualitatif, dimana metodologi kualitatif merupakan prosedur penelitian yang menghasilkan data deskriptif berupa kata-kata tertulis atau lisan dari orang-orang dan perilaku yang dapat diamati.

Berdasarkan maksud penelitian tersebut, penulis menggunakan jenis penelitian etnometodologi. Garfinkel (1967) mendefiniskan etnometodologi sebagai studi tentang bagaimana orang-orang sebagai pendukung dari tatanan yang lazim menggunakan sifat-sifat tatanan itu untuk agar bagi para warga dapat terjadi ciri-ciri terorganisasi yang kelihatan nyata. Para ahli etnometodologi berupaya bagaimana cara orang memandang, menjelaskan, dan memberikan tatanan di dunia tempat hidupnya.

Sukidin (2002), etnometodologi adalah suatu studi empiris tentang bagaimana orang menanggapi pengalaman dunia sosialnya sehari-hari. Etnometodologi mempelajari realitas sosial atas interaksi yang berlangsung sehari-hari.

Kurniawan (2012) mendefinisikan bahwa etnometodologi merupakan sebuah studi tentang bagaimana memahami perilaku individu-individu dalam sebuah lingkungan sosial sehari-hari menyelesaikan permasalahan atau pekerjaan yang mereka hadapi.

Dalam pengamatannya, etnometodologi berusaha untuk memahami perspektif dari individu dalam menyelesaikan sebuah permasalahan. Ide besar dalam etnometodologi adalah bahwa kegiatan yang dilakukan individu berupa interaksi dan perilaku yang terjadi dalam sebuah lingkungan sosial mungkin dilakukan dalam berbagai bentuk keahlian. Hasil pengamatan atas perilaku dan sudut pandang individu inilah yang kemudian dipadukan 
dengan intuisi peneliti untuk kemudian dijadikan referensi dalam mengkonsep sebuah pemahaman.

Data utama dari penelitian ini dikumpulkan dari hasil wawancara, dan pengamatan terhadap kegiatan, perilaku, perkataan informan yaitu pemilik warung makan, dalam hal ini Mba Citra dan Mas Djarwo.

\section{HASIL PENELITIAN DAN PEMBAHASAN}

Kebersahajaan dan kesederhanaan karakter pemilik warung makan ini dalam kesehariannya yang kemudian diimplikasikan dalam kegiatan usaha mereka, sehingga dalam penetapan harga yang hampir tidak dinaikkan meskipun harga bahan pokok sedang naik, warung makan ini tetap memandapatkan laba yang cukup lumayan, menarik perhatian peneliti yang merupakan pelanggan tetap warung makan ini, untuk meneliti di tempat ini. Dalam bagian ini dilakukan analisis terhadap hasil wawancara yang dilakukan kepada narasumber terkait penentuan harga yang diterapkan dalam usaha warung makan ini.

Berbisnis memang pada awalnya bertujuan untuk mencari keuntungan, dengan berbagai cara sang pemilik bisnis menggunakan strategi-strategi untuk mendapatkan laba yang sebesar-besarnya. Mindset mengenai keuntungan yang besar biasanya dijadikan factor tolak ukur apakah sebuah bisnis itu berhasil atau tidak. Namun tak jarang, beberapa bisnis menyelipkan tujuan lainnya selain mendapatkan keuntungan, tujuan-tujuan inilah yang diterapkan sang pemilik agar mendapatkan hasil-hasil tertentu yang diinginkan sang pemilik.

Mayoritas agama yang dianut oleh etnis Jawa adalah agama Islam, agama yang mengajarkan tentang kebaikan sesama dan setiap kebaikan yang dilakukan setiap manusia akan berbalik kepada diri mereka sendiri, sehingga Mba Citra dan Suaminya menerapkan kebaikan tersebut didalam usahanya. Agama Islam tidak hanya mengajarkan tata cara beribadah kepada Tuhan tetapi juga mengajarkan bagaimana tata cara bermasyarakat dengan sesama manusia. Hal ini diterapkan karena tidak lepas dari perintah dan larangan Allah S.W.T dalam firman-Nya.

”Barang siapa berbuat baik (amal baik), maka pahalanya untuk dirinya sendiri

... “(QS 41:46)

"Barangsiapa yang mengerjakan kebaikan seberat dzarrah niscaya dia akan menerima (balasan)nya. Dan barangsiapa yang mengerjakan kejahatan seberat dzarrah-pun, niscaya dia akan menerima (balasan)nya”. (QS 99:7-8).

Sebagai orang Jawa pun, hal ini menjadi panutan bagi Mba Citra dan Mas Djarwo, dimana mamah (rizqi) merupakan proses kedua setelah obah (bekerja). Mamah yang 
diharapkan adalah benar-benar berasal dari pekerjaan yang halal. Konsep mamah sangat menekankan pada nilai-nilai ketuhanan. Hal ini ditunjukkan dengan ungkapan paring panglilane gusti "pemberian sesuai dengan kerelaan Tuhan". Bagi masyarakat Jawa, kerelaan Tuhan menjadi tujuan utama untuk mendapatkan rizqi yang berkah. Sebagai konsekwensinya adalah menyisihkan sebagian dari rizqi yang diterima untuk diberikan kepada yang berhak.

Seluruh perintah Allah S.W.T dan wewejangan hidup suku Jawa teraplikasi dalam keseharian Mba Citra dan Mas Djarwo, salah satunya dalam kegiatan berdagang. Perilaku obah (bekerja) dan ketekunan serta kerja keras mereka tercermin dari pasangan Suami dan Istri ini yang memulai persiapan dagangannya di pagi-pagi buta sebelum fajar menyingising, disaat tetaangga-tetangga sekitar bahkan belum terbangun dari tidur mereka, dibantu oleh saudara perempuannya Mba Citra, berdagang dari pagi sampai malam, untuk memenuhi kebutuhan pokok baik untuk sarapan, hingga makan malam tetangga-tetangganya terutama anak-anak kos, dengan menu-menu makanan yang bervariasi setiap harinya.

Dalam hal penentuan harga, Mba Citra dan Mas Djarwo tidak mematok harga yang tinggi. Semuanya sesuai dengan kantong anak kos-kosan yang kebanyakan adalah para mahasiswa yang sedang merantau demi menuntut ilmu. Tujuan utama Mba Citra dan Mas Djarwo adalah bukan hanya mendapatkan laba untuk memenuhi kebutuhan keluarganya sehari-hari tetapi juga sekaligus menolong sesama agar bisa menikmati masakannya dengan harga yang ramah, terjangkau dan memenuhi kebutuhan pokok para pelanggannya.

Sebagaimana dengan ungkapan tuna satak bathi sanak dalam pergaulan para bakul (pedagang). Yang artinya, rugi uang asal untung saudara. Ungkapan yang sering ditemukan dalam pergaulan para bakul (pedagang) tersebut menunjukkan bahwa kebahagiaan orang berdagang tidak selalu diukur dengan keuntungan berupa uang. Bagi seorang pedagang yang dalam bahasa jawa disebut bakul, mendapatkan saudara atau rekanan dalam berusaha pun dihitungnya sebagai keuntungan (laba).

Oleh sebab itu, Mba Citra dan Mas Djarwo rela menjual barang dagangannya dengan mematok harga yang tidak tinggi demi menjalin hubungan dengan orang lain, yakni dalam hal ini para pelanggan (pembeli). Bagi pasangan suami istri ini, harta bukanlah segala-galanya. Satu hal yang sederhana dari keinginan mereka adalah mereka dapat menghidupi dan membiayai kehidupan dan sekolah anak-anak mereka.

Disamping itu juga, sedikit laba yang didapat dari usaha warung makan ini dizakatkan kepada para mustahiq zakat. Konsep ini dapat kita sebut dengan price setting sosial dimana penentuan harga diterapkan untuk membantu sesama, sebagian uang yang didapat dari sebuah 
usahanya sejatinya adalah milik orang lain, maka dari itu Mba Citra harus mengeluarkannya dalam bentuk zakat ataupun juga sedekah.

Beberapa usaha ataupun bisnis memprioritaskan laba dari produk yang dijual, ataupun meningkatan turn over penjualannya. Baridwan (2004:149) Secara umum istilah persediaan barang dipakai untuk menunjukan barang-barang yang dimiliki untuk dijual kembali dan digunakan untuk memproduksi barang-barang yang akan dijual. Warung makan yang menjual kebutuhan pokok pastinya akan memiliki pembeli, karena dibutuhkan oleh setiap manusia.

Dengan menjual kebutuhan pokok, warung makan Mba Citra tidak perlu menetapkan laba yang terlalu tinggi, karena mempunyai turn over yang cukup, sebab warung makan Mba Citra memiliki pelanggan yang banyak dan tetap untuk tiap harinya. Sebenarnya, dalam sebuah bisnis warung makan seperti kebanyakan bisnis rumah makan lainnya yang terdiri dari bahan baku pembuatan yakni bahan masakan, tenaga kerja (karyawan) dan biaya-biaya overhead khusus bisnis warung makan seperti gas, minyak goreng, dan lain-lainnya, harga jual makanan-makanan tersebut mungkin akan menjadi berkali-kali lipat. Tetapi hal ini tidak dilakukan oleh warung makan Mba Citra karena konsep yang mereka terapkan adalah price setting sosial.

Dan juga memiliki kegiatan rutin yakni kegiatan membeli bahan baku dan keperluan lainnya atau yang biasa disebut dengan belanja atau order. Kegiatan belanja warung makan Mba Citra biasanya hampir sama dengan kebanyakan rumah makan lainnya, ada yang diantar langsung ketempat pembeli dalam hal ini Mba Citra, juga dengan membelinya langsung kepasar atau membelinya pada pedagang-pedagang keliling.

Kegiatan belanja berfokus pada bahan baku masakan yang akan dimasak pada hari itu, dan juga pada bumbu-bumbu. Bumbu-bumbu ini menjadi perhatian penting, karena perbedaan penggunaan bumbu akan mempengaruhi rasa masakan Mba Citra yang khas, pelanggan yang merasakan perubahan pada cita rasa masakan Mba Citra, biasanya akan melakukan complain dan bila terjadi terus menerus, bukan hal yang tidak mungkin pelanggan akan meninggalkan warung makan ini.

Sudah sewajarnya bahwa warung makan pastinya akan menyediakan menu masakan yang banyak dan beragam, salah satu tujuannya adalah memperbanyak laba dari banyaknya menu tersebut. Menu masakan yang bermacam-macam membuat warung makan Mba Citra harus menyediakan berbagai jenis masakan pula. Dan juga, Mba Citra harus membeli bahan baku yang beragam pula untuk memenuhi kebutuhan tersebut. 
Semakin beragam menu masakan akan membuat pembelian bahan baku yang beragam pula, hal ini akan membuat pengeluaran warung makan Mba Citra menjadi banyak. Namun hal ini merupakan suatu kewajiban bagi Mba Citra, karena bila tidak mampu menyediakan menu yang beragam dan hanya memberikan menu yang sama, tentu akan membuat pelanggan bosan sehingga akan membuat pelanggan beralih ke pesaing (warung makan lainnya).

\section{KESIMPULAN DAN SARAN}

\section{Kesimpulan}

Rumah makan ataupun warung makan merupakan usaha yang lumayan menguntungkan, merupakan turunan dari bisnis kuliner yang menjual makanan pokok yang dibutuhkan manusia sehari-hari, maka sangat jarang bila bisnis ini sepi dari pembeli. Namun tidak ada bisnis atau usaha yang tidak mempunyai resiko, meskipun itu hanya sedikit. Usaha warung makan juga mempunyai resiko yang harus bisa diantisipasi oleh pemilknya.

Penghasilan yang cukup lumayan dari pendapatan hasil penjualannya, maka akan sangat mudah menemui warung-warung makan lainnya (pesaing). Jenis makanan yang bervariasi untuk setiap harinya, dan lengkap lauk dan pauknya. Selain itu harga yang murah merupakan senjata warung makan Mba Citra yang ampuh dalam menghadapi persaingan usahanya secara sehat. Harga yang mahal akan menyulitkan dalam menarik pelanggan, sebaliknya harga yang murah malah nantinya mengakibatkan usaha warung makan ini justru rugi.

Penentuan harga yang tepat adalah cara yang tepat untuk melakukan persaingan. Penentuan harga dalam usaha warung makan Mba Citra ini sangat ditekankan pada komponen pembuatan masakan, dari mulai bahan baku, bahan pelengkap. Uniknya penentuan harga dalam usaha warung makan Mba Citra menarik peneliti untuk membahasnya, sebab tidak seperti warung makan lainnya yang bertujuan untuk mendapatkan untung sebesar-sebesarnya dengan menaikkan harga makanan berkali-kali lipat dari harga bahan pokok pembuatannya, tetapi justru di warung makan Mba Citra ini penentuan harganya tidak hanya bertujuan untuk mendapatkan keuntungan yang sebesar-besarnya tapi juga mempunyai faktor lainnya sebagai niat untuk menolong sesama. Menolong para pelanggannya yang kebanyakan adalah anak kos-kosan untuk memenuhi kebutuhan pokok mereka dengan harga yang pas di kantong namun tetap enak. Meskipun akhir-akhir ini semua harga bahan pokok naik menyusul kenaikkan harga BBM.

\section{Saran}


Berdasarkan hasil penelitian yang sudah dibahas sebelumnya, ada beberapa usulan dan saran dari peneliti, mengenai price setting yang diterapkan Mba Citra dan suaminya Mas Djarwo yang mengusung konsep price setting sosial dimana kedua pasangan suami istri ini berdagang bukan semata-mata untuk memperoleh laba, tetapi ada hal yang menurut mereka penting yakni untuk memenuhi kebutuhan pokok tetangga-tetangga mereka yang didominasi oleh anak-anak kos. Harapan saya, semoga hasil penelitian ini dapat memberi wawasan pada masyarakat luas bahwasanya banyak cara yang dapat ditempuh agar dapat memahami suatu ilmu pengetahuan lebih khususnya mengenai pemahaman Akuntansi dan harga, tidak hanya dari satu sudut pandang saja tetapi dari berbagai macam aspek yang justru lebih sederhana.

\section{DAFTAR PUSTAKA}

Baridwan, Zaki. 2004. Intermediate Accounting, Edisi Kedelapan. Yogyakarta: BPFE. Djaslim Saladin (2006). Manajemen Pemasaran. Bandung : Lina Karya.

Kurniawan, R. 2012. Valuasi Aset Biologis: Kajian Kritis atas IAS 41 Mengenai Akuntansi.

Moleong, Lexy J. 2004. Metode Penelitian Kualitatif. Bandung: Remaja Rosdakarya.

Marbangun, Hardjowirogo. 1995. Manusia Jawa. Jakarta: PT Toko Gunung Agung.

R.S.N Pillai and Bagavathi. 2002. Modern Marketing Principles and Practices. S. Chand \& Company LTD. New Delhi.

Sukidin, Basrowi. 2002. Metode Penelitian Kualitatif Perspektif Mikro. Surabaya: Insan Cendekia 